\title{
PRODUCTION AND CHARACTERIZATION OF BACTERIOCIN PRODUCED BY LACTIC ACID BACTERIA ISOLATED FROM RUSIP
}

\section{Produksi dan Karakterisasi Bakteriosin yang Dihasilkan oleh Bakteri Asam Laktat yang Diisolasi dari Rusip}

\author{
Arifah Kusmarwati*, Ninoek Indriati, and Irma Hermana ${ }^{1}$ \\ ${ }^{1}$ Research and Development Center for Marine and Fisheries Product Processing and Biotechnology, \\ Jl. K.S. Tubun Petamburan VI, Jakarta Pusat 10260, Indonesia \\ ${ }^{*}$ Correspondence author: iin_amri@yahoo.com \\ Article history: \\ Received 9 Juli 2012, Received in revised form 4 April 2013, Accepted 5 April 2013
}

\begin{abstract}
Research was conducted to produce and characterize bacteriocin produced by lactic acid bacteria ( $L A B$ ) isolated from rusip, a traditional Bangkanese fermented fish product. Experiment was started by isolation of lactic acid bacteria from rusip, followed by screening to obtain the best isolate which has the highest bacterial inhibition activity. The selected isolate was then identified and used to produce crude bacteriocin. The crude bacteriocin was characterized through its stability in high temperature and proteolytic enzymes, inhibitory spectrum, $\mathrm{pH}$ sensitivity and effect of surfactants. The result showed that $\mathrm{CN} 1.10 \mathrm{a}$ isolate which was identified as Lactococcus lactis subsp lactis has the highest bacterial inhibition activities; therefore it was selected to produce crude bacteriocin. The bacteriocin produced was heat stable, sensitive to proteolytic enzymes i.e. proteinase-K and papain but not to RNase. It inhibited Escherichia coli, Listeria monocytogenes and Lactobacillus plantarum. It stable at $\mathrm{pH} 2.0$ to 6.0. Among surfactans used sodium dodecyl sulphate (SDS), lauryl sarcosine and EDTA were able to stimulate bacteriocin production, while the production were strongly inhibited by Tween 20 , Tween 80 , Triton X-100 and urea. Based on the above characteristic, the bacteriocin was suitable to be used as a preservative of food which has to be processed at high temperature.
\end{abstract}

Keywords: heat stable, bacteriocin, Lactococcus lactis, rusip

\begin{abstract}
ABSTRAK
Penelitian ini dilakukan untuk memproduksi dan mengkarakterisasi bakteriosin yang dihasilkan oleh bakteri asam laktat hasil isolasi dari rusip, produk ikan fermentasi tradisional Bangka. Penelitian dimulai dari isolasi bakteri asam laktat dari rusip, dilanjutkan dengan skrining untuk memperoleh isolat terbaik yang menghasilkan aktivitas penghambatan bakteri tertinggi. Isolat terpilih selanjutnya diidentifikasi dan digunakan untuk memproduksi bakteriosin kasar. Bakteriosin kasar dikarakterisasi melalui pengujian stabilitasnya terhadap suhu tinggi dan enzim proteolitik, spektrum penghambatan, sensitivitas $\mathrm{pH}$ dan pengaruh surfaktan. Hasil penelitian menunjukkan bahwa isolat CN1.10a yang kemudian diidentifikasi sebagai Lactococcus lactis subsp lactis merupakan satu-satunya isolat yang menghasilkan bakteriosin dengan aktivitas penghambatan bakteri tertinggi, sensitif terhadap enzim proteolitik seperti proteinase-K dan papain namun tidak terhadap RNase. Bakteriosin L. lactis subsp lactis tersebut dapat menghambat Esherichia coli, Listeria monocytogenes dan Lactobacillus plantarum, dan stabil pada $\mathrm{pH}$ 2-6. Di antara surfaktan yang digunakan, sodium dodecyl sulphate (SDS), lauryl sarcosine dan EDTA mampu menstimulasi produksi bakteriosin sedangkan Tween 20 , Tween 80 , Triton X-100 dan urea sangat kuat menghambat produksi bakteriosin. Berdasarkan karakteristik tersebut maka bakteriosin sesuai untuk digunakan sebagai pengawet pangan yang harus diproses pada suhu tinggi.
\end{abstract}

Kata Kunci: tahan panas, bakteriosin, Lactococcus lactis, rusip

Permalink/DOI: http://dx.doi.org/10.15578/squalen.v8i1.77

\section{INTRODUCTION}

Bacteriocins are defined as proteins or protein complexes antagonistic to bacteria genetically closely related to the producer organisms (De Vuyst \& Vandamme, 1994; Klaenhammer, 1988). They are ribosomally-synthesized peptides or proteins with antimicrobial activity, produced by different groups of bacteria (Galvez et al., 2007).

Many lactic acid bacteria produce bacteriocins with rather broad spectra of inhibition (Galvez et al., 2007). Bacteriocins from lactic acid bacteria (LAB) are more interested than other resources, because 
most of $L A B$ are related to fermented foods. Many novel bacteriocin-producing $L A B$ from fermented food have been isolated, produced and characterized. For example, bacteriocin produced by LAB isolated from Sucuk, Turkish fermented meat, vacuum-packed meat product, Pentocin 31.1, bacteriocin produced by Lactobacillus pentosus 31-1 isolated from Xuan-Wei Ham, a traditional China fermented meat product, China fermented cabbage, artisanal dry sausages, and bacteriocin produced by Lactococcus lactis strain isolated from charqui, a Brazilian fermented, salted and dried meat product (Hilmi CE on \& GoE kalp, 2000; Budde et al., 2003; Gao et al., 2010; Abrams et al., 2011; Castro et al., 2011; Biscola et al., 2013). The other bacteriocins were also produced by strains Lactobacillus plantarum, L. brevis, Pediococcus acidilactici, $L$. pentosus and $L$. lactis (Osmanagaoglu et al., 1997; Ogunbanwo et al., 2003; Todorov \& Dicks, 2005; Omar et al., 2006; Liu et al., 2008; Alegria et al., 2010; Rajaram et al., 2010). Although many bacteriocins are produced by those species, only nisin has GRAS (generally recognized as safe) status and remains the only commercially important bacteriocin being approved as a food preservative (Cleveland et al., 2001). The bacteriocin is commonly used as natural preservatives in meat products, processed cheese and canned vegetables (Abrams et al., 2011; Albano et al., 2008 in Karthikeyan \& Santhosh, 2009; De Arauza et al., 2009). The FAO/WHO Codex Committee on milk and milk products has accepted nisin as a food additive for processed cheese at a concentration of $12.5 \mathrm{mg}$ pure nisin per kilogram product (Ross et al., 2002 in De Arauz et al., 2009).

Indonesia has many kinds of fermented fish products, one of them is rusip. Rusip composed of fish, salt, brown sugar and soaked water from dried rice but sometimes without rice. It produced by spontaneous fermentation during 7-14 days anaerobically (Yuliana, 2007). Rusip mainly produced in Bangka Belitung Provinces and widely used as a condiment or mixed with chili sauce and consumed with boiled rice and vegetables. Rusip contains mainly lactic acid bacteria (LAB) such as Lactobacillus, Streptococcus, Leuconostoc, Pediococcus, and Enterococcus (Dessi, 1999 in Yuliana, 2007; Wijaya, 2007 in Sakti, 2009). Staphylococcus aureus sometimes has also been found in rusip (Kusmarwati et al., 2001).

Studies on the exploration of bacteriocin produced by Indonesian fermented food are still limited. Some of the results that have been reported are bacteriocin from meat product and milk-associated lactic acid bacteria (Rahayu et al., 1999; Kusmiati \& Malik, 2002; Nugroho \& Rahayu, 2003; Usmiati \& Marwati, 2007; Syahniar, 2009). This present work was aimed to screen lactic acid bacteria from rusip, produce and characterize the bacteriocin produced by the selected bacteria isolate which has potential to produce a high stable activity of bacteriocin.

\section{MATERIALS AND METHODS}

\section{Sample Collection}

Rusip samples were collected between the year of 2011 and 2012 from Bangka, Belitung and Palembang regions, Indonesia. They were obtained from different producers which applied different methods of production. The samples were stored at $4^{\circ} \mathrm{C}$ in Microbiology Laboratory at the Research and Development Center for Marine and Fisheries Product Processing and Biotechnology (RDCMFPPB), Jakarta, where the experiments were conducted.

\section{Isolation and Screening of Lactic Acid Bacteria}

Lactic acid bacteria were isolated from rusip, using dilution method followed by pour plate method on MRS (deMan Rogosa and Sharpe) agar contained $1 \%$ (w/ v) $\mathrm{CaCO}_{3}$ (Rahayu \& Margino, 1997). Twenty-five grams of sample were added to $225 \mathrm{ml}$ of sterile butterfield phosphate buffer (BPF) and shaken for $1 \mathrm{~min}$. An appropriate decimal dilutions were prepared in $9 \mathrm{ml}$ of BPF, $1 \mathrm{ml}$ of each dilution was poured into a sterile petri dish followed by MRS agar media. Cultures were then incubated at $37^{\circ} \mathrm{C}$ for $48 \mathrm{~h}$. Bacterial colonies that exhibited clear zone on MRS agar plate were individually picked and streaked on MRS agar containing $1 \%(\mathrm{w} / \mathrm{v}) \mathrm{CaCO}_{3}$. This procedure was repeated to obtain pure isolates. Each of the isolate was first Gram stained and examined microscopically. Gram positive isolates were then tested for catalase, and isolates which showed catalase negative were identified as lactic acid bacteria. Catalase test was conducted by placing a drop of $3 \%$ hydrogen peroxide solution on the isolate. Immediate formation of bubbles indicated the presence of catalase in the cells (catalase positive). Those isolates which have catalase negative were then maintained in MRS broth containing $20 \%$ glycerol and $10 \%$ skim milk at $-20^{\circ} \mathrm{C}$ for 3 months. The isolates were subcultured onto MRS agar slant, incubated at $37^{\circ} \mathrm{C}$ for 48 hours before used for the next steps of the experiment.

\section{Screening of Lactic Acid Bacteria for Antimicrobial Activity}

Escherichia coli ATCC 25922 and Listeria monocytogenes ATCC 19115 which obtained from Oxoid, America; Lactobacillus plantarum and Lactobacillus fermentum were obtained from culture 
collection of the RDCMFPPB, Jakarta. Those microorganisms were used as tested bacteria in antimicrobial activity assay. Antimicrobial activity against tested bacteria was determined by agar spotted on the lawn method (Abrams et al., 2011) under aerobic condition. Muller Hinton Agar (MHA) plate were inoculated with $100 \mu \mathrm{l}$ of each tested bacteria after growing them in nutrient broth for $E$. coli, brain hearth infusion (BHI) for Listeria monocytogenes and MRS broth for $L$. plantarum. MHA plate contained each of the tested bacteria were then spotted on lawns of $10 \mu \mathrm{LAB}$ culture in MRS broth and incubated overnight at $37^{\circ} \mathrm{C}$. The isolate recorded as positive to have antimicrobial activity if a transparent halo zone is observed around the spot.

\section{Production of Crude Bacteriocin}

Production of crude bacteriocin followed the method of Ogunbanwo et al. (2003). The isolates were grown in MRS broth at $37^{\circ} \mathrm{C}$ for $48 \mathrm{~h}$. After incubation, the broth was centrifuged at $10.000 \mathrm{xg}$ for $15 \mathrm{~min}$ at $4^{\circ} \mathrm{C}$. The cell free supernatant was adjusted to $\mathrm{pH} 6.0$ by adding $1 \mathrm{M} \mathrm{NaOH}$ to exclude the antimicrobial effect of organic acid, followed by filtration of the supernatant through $0.2 \mu \mathrm{m}$ pore-size cellulose acetate filter and heated at $100^{\circ} \mathrm{C}$ for $15 \mathrm{~min}$. The cell free supernatant was regarded as crude bacteriocin.

\section{Bacteriocin Assay}

Crude bacteriocin produced were tested against the same tested bacteria using the same method as antimicrobial test for LAB. Bacteriocin assay was determined by agar spotted on the lawn method under aerobic condition (Abrams et al., 2011). The inhibitory activity was tested on MHA. MHA plate contained each of tested bacteria were then spotted on lawns of $10 \mu \mathrm{L} L A B$ culture in MRS broth and incubated overnight at $37^{\circ} \mathrm{C}$. The crude bacteriocin is recorded to have antimicrobial activity if a transparent halo zone is observed around the spot. The bacteriocin which showed the highest antimicrobial activity was selected for sensitivity test againts proteolytic enzyme.

\section{Sensitivity of Bacteriocin to Proteolytic Enzymes}

Crude bacteriocin was assayed to various proteolytic enzymes i.e. proteinase- $\mathrm{K}$ in $0.05 \mathrm{M}$ Tris hydrochloride $(\mathrm{pH} 8.0)$; papain in $1 \mathrm{~N} \mathrm{NaOH}(\mathrm{pH} 6.5)$ and ribonuclease-A in $0.05 \mathrm{M}$ Tris hydrochloride $(\mathrm{pH}$ 8.0). About $200 \mu \mathrm{l}$ aliquot of crude bacteriocin was added with $2 \mathrm{mg} / \mathrm{ml}$ of each enzyme and incubated for $60 \mathrm{~min}$ at $37^{\circ} \mathrm{C}$. Bacteriocin without the addition of enzyme was used as a control. All tubes were assayed for antimicrobial activity using agar well diffusion method (Ogunbanwo et al., 2003; Udhayashree et al., 2012). MHA plate were inoculated with $100 \mu \mathrm{l}$ of $L$. plantarum which was previously grown in MRS broth at $37^{\circ} \mathrm{C}$ for $24 \mathrm{~h}$. Wells $(6 \mathrm{~mm})$ were prepared in MHA plate and $10 \mu \mathrm{l}$ of crude bacteriocin was added into each well. Plates were incubated at $37^{\circ} \mathrm{C}$ for $24 \mathrm{~h}$. Only those cell free supernatants which are sensitive to proteinase-K and papain were considered as real bacteriocin and chosen for following steps. The cell free supernatant that was considered sensitive to proteolytic enzyme, i.e no transparent halo zone surrounded the wells, were recorded as negative result.

\section{CHARACTERIZATION OF BACTERIOCIN}

\section{Effect of $\mathrm{pH}$}

About $5 \mathrm{ml}$ aliquot of crude bacteriocin was put in test tube and the $\mathrm{pH}$ was adjusted to $2,4,6,8,10$, and 12 individually using either diluted $\mathrm{NaOH}$ or $\mathrm{HCl}$. After the samples incubated for $4 \mathrm{~h}$ at room temperature, the antimicrobial activity was assayed by using agar well diffusion method. Antimicrobial activity was expressed as arbitrary unit (AU) per ml. Using this method, one AU was defined as the area of inhibition zone per volume of bacteriocin sample $\left(\mathrm{mm}^{2} /\right.$ ml) (Usmiati \& Marwati, 2007).

bacteriocin activity $\left(\mathrm{mm}^{2} / \mathrm{ml}\right)=1 \mathrm{AU} / \mathrm{ml}$

$$
=\frac{L z-L s}{V}
$$

Note :

$\mathrm{Lz}=$ The area of transparent zone $\left(\mathrm{mm}^{2}\right)$

$\mathrm{Ls}=$ The area of well $\left(\mathrm{mm}^{2}\right)$

$\mathrm{V}=$ volume of sample $(\mathrm{ml})$

\section{Heat Stability}

About $2 \mathrm{ml}$ aliquot of crude bacteriocin in tube was heated at $80^{\circ} \mathrm{C}$ and $115^{\circ} \mathrm{C}$ for $20 \mathrm{~min}$ and $121^{\circ} \mathrm{C}$ for $15 \mathrm{~min}$. The heat treated bacteriocins were then assayed for antimicrobial activity using agar well diffusion method as was described on point sensitivity of bacteriocin to proteolytic enzymes. Crude bacteriocin is considered as heat stable when there is transparent halo zone surrounded the wells (recorded as positive). Quantification of bacteriocin activity $(\mathrm{AU} / \mathrm{ml})$ was described above.

\section{Effect of Surfactans}

The surfactants tested were Triton X-100, Tween 20 , Tween 80 (non ionic), sodium dodecyl sulphate/ SDS (anionic), EDTA, Urea and N-Laurylsarcosine (dipolar ionic). The surfactants were added to each aliquot of crude bacteriocin at the concentration of $0,1 \mathrm{ml}$ or $0,01 \mathrm{~g}$ of surfactant per ml crude bacteriocin. Aliquot of the crude bacteriocin without surfactant was 
used as a control. After all samples and control were incubated at $37^{\circ} \mathrm{C}$ for $60 \mathrm{~min}$, the bacteriocin activity was assayed as described above.

\section{Antimicrobial Activity of Bacteriocin}

Antibacterial activity of bacteriocin was assayed to some tested bacteria ( $L$. plantarum, $L$. monocytogenes, S. typhimurium and $E$. coli) using agar well diffusion method as described on point sensitivity of bacteriocin to proteolytic enzymes. MHA plate were inoculated with each $100 \mu$ l of the tested bacteria after growing them in MRS broth for $L$. plantarum and nutrient broth for $L$. monocytogenes, S. thypimurium and $\mathrm{E}$. coli at $37^{\circ} \mathrm{C}$ for $24 \mathrm{~h}$. Wells $(6$ $\mathrm{mm}$ ) were prepared in MHA plate and $10 \mu \mathrm{l}$ of crude bacteriocin was added into each well. Plates were incubated at $37^{\circ} \mathrm{C}$ for $24 \mathrm{~h}$. The antimicrobial activity recorded as positive if a transparent halo zone was observed around the well. Quantification of bacteriocin activity $(\mathrm{AU} / \mathrm{ml})$ was described above.

\section{Identification of Selected Isolate}

The selected isolate was identified using API 50 $\mathrm{CH}$ strips and API $50 \mathrm{CHL}$ medium (API systems, Biomerieux Sa, French).

\section{RESULTS AND DISCUSSIONS}

\section{Isolation of Lactic Acid Bacteria from Rusip}

Twenty seven isolates of the lactic acid bacteria were isolated from rusip originated from Palembang,

Table 1. The morphology and Gram stain of lactic acid bacteria isolated from rusip

\begin{tabular}{cllcc}
\hline No & Origin of Rusip & Isolate & Cell Morphology & Gram Stain \\
\hline 1 & Palembang & SW1.12 & rod & + \\
2 & Palembang & SW1.1b & rod & + \\
3 & Palembang & SW2.1bl & rod & + \\
4 & Palembang & SW2.1c & rod & + \\
5 & Palembang & SW2.12d & rod & + \\
6 & Palembang & SW2.11 & rod & + \\
7 & Palembang & SW2.1b II & rod & + \\
8 & Palembang & SW2.12b & rod & + \\
9 & Palembang & SW2.1dl & rod & + \\
10 & Bangka & CN1.10a & rod & + \\
11 & Bangka & CN11a & rod & + \\
12 & Bangka & CN1.8 & rod & + \\
13 & Bangka & CN1.7b & rod & + \\
14 & Belitung & BL2.12 & coccus & + \\
15 & Belitung & BL1.2 & coccus & + \\
16 & Belitung & BL1.9b & coccus & + \\
17 & Belitung & BL2.4 & coccus & + \\
18 & Belitung & BL2.13 & coccus & + \\
19 & Belitung & BL1.4 & coccus & + \\
20 & Belitung & BL1.11 & coccus & + \\
21 & Belitung & BL2.10a & coccus & + \\
22 & Belitung & BL2.16a & coccus & + \\
23 & Belitung & BL1.6 & coccus & + \\
24 & Belitung & BL2.16b & coccus & + \\
25 & Belitung & BL1.10 & Coccus & + \\
26 & Belitung & BL2.18 & Coccus & + \\
27 & Belitung & BL2.6 & Coccus & + \\
\hline & & & & + \\
\hline
\end{tabular}


Bangka and Belitung (Table 1). Gram stained analysis showed 13 strains as Gram-positive rod and 14 strains as Gram-positive coccus.

\section{Screening of Lactic Acid Bacteria for Anti-microbial Activity}

Antimicrobial activity against Gram negative bacteria is an unusual phenomenon and has rarely been reported (Abrams et al., 2011). However 17 isolates in this experiment exhibited activity against E. coli during the first screening by the development of clear zones (inhibition zone) around the spot. Roth \& Keenan (1971) in Hwanhlem et al., 2011 reported that lactic acid was able to cause sub-lethal injury to E. coli, and similar properties have also been assigned to acetic acid (Przybylski \& Witter, 1979 in Hwanhlem et al., 2011). Indirect evidence suggests that such injury involves disruption of the lipopolysaccharide (LPSP) layer. Out of 17 isolates, 7 strains were also active against $L$. plantarum, 10 isolates were active against $L$. fermentum and 5 isolates were only active against $L$. plantarum and $L$. fermentum (Table 2). Based on this first screening result, some isolates showed large spectrum of inhibition to Gram positive (L. plantarum and $L$. fermentum) and negative bacteria (E. coli). The inhibition zone may be due to the competition for nutrients on the production of bacteriocin, lactic acid, diacetyl, bacteriocin or hydrogen peroxide during culture (Klaenhammer, 1988 in Liu et al., 2008; Abrams et al., 2011).

\section{Production and Characterization of Bacteriocin}

Crude bacteriocins produced by 19 isolates were obtained from the supernatant of all strains after grown in MRS media at $37^{\circ} \mathrm{C}$ for 48 hours.

Among 19 supernatant from rusip, CN1.10a and SW2.11 supernatant showed a larger inhibition zone than others (Table 3). Hence, both CN1.10a and SW2.11 supernatants were tested to the sensitivity againts the proteolytic enzymes to confirm those supernatants as bacteriocin.

Bacteriocin is defined as proteins or protein complexes antagonistic to bacteria (De Vuyst \& Vandamme, 1994). As shown in Table 4, the activity of $\mathrm{CN} 1.10 \mathrm{a}$ bacteriocin was lost after being treated

Table 2. Result of antimicrobial activity of the lactic acid bacteria

\begin{tabular}{clccc}
\hline & & \multicolumn{3}{c}{ Inhibition zone (mm) } \\
\cline { 3 - 5 } No & Isolates & $\begin{array}{c}\text { Escherichia coli } \\
\text { ATCC 25922 }\end{array}$ & L. plantarum & L. fermentum \\
\hline 1 & SW1.12 & 5 & 0 & 6 \\
2 & SW1.1b & 6 & 0 & 0 \\
3 & SW2.1bl & 6 & 0 & 7 \\
4 & SW2.1c & 6 & 0 & 0 \\
5 & SW2.12d & 6 & 7 & 0 \\
6 & SW2.11 & 7 & 6 & 6 \\
7 & CN1.10a & 7 & 0 & 9.5 \\
8 & SW2.1b II & 6 & 0 & 0 \\
9 & SW2.12b & 9 & 0 & 0 \\
10 & SW2.1dl & 6 & 0 & 0 \\
11 & BL2.12 & 7 & 16 & 4 \\
12 & BL1.2 & 7 & 0 & 4 \\
13 & BL1.9b & 6 & 0 & 0 \\
14 & BL2.4 & 6 & 0 & 0 \\
15 & BL2.13 & 0 & 26.5 & 7 \\
16 & BL1.4 & 6 & 7 & 6 \\
17 & BL1.11 & 6 & 0 & 8.5 \\
18 & BL2.10a & 0 & 15 & 0 \\
19 & CN11a & 5 & 7.5 & 2 \\
\hline
\end{tabular}


Table 3. Results of antimicrobial activity of crude bacteriocin

\begin{tabular}{ccccc}
\hline \multirow{2}{*}{ Isolate } & \multicolumn{2}{c}{ Inhibition Zone $(\mathrm{mm})$} & \multicolumn{2}{c}{ Bacteriocin Activity (AU/mI) } \\
\cline { 2 - 5 } & E. coli & L. plantarum & E. coli & L. plantarum \\
\hline SW1.12 & $7.83 \pm 1.04$ & $12.67 \pm 0.58$ & 1.265 & 6.226 \\
SW1.1b & $7.67 \pm 0.76$ & $10.33 \pm 1.15$ & 1141 & 3535 \\
SW2.1bl & $7.67 \pm 0.29$ & $9.67 \pm 0.29$ & 1141 & 2875 \\
SW2.1c & $8.50 \pm 0.50$ & $11.00 \pm 1.00$ & 1813 & 4250 \\
SW2.12d & $6.33 \pm 2.89$ & $11.33 \pm 0.58$ & 203 & 4618 \\
SW2.11 & $10.00 \pm 0.87$ & $10.33 \pm 1.53$ & 3200 & 3535 \\
CN1.10a & $10.25 \pm 2.47$ & $11.67 \pm 2.89$ & 3453 & 5009 \\
SW2.1b II & $9.67 \pm 0.29$ & $9.67 \pm 1.61$ & 2875 & 2875 \\
SW2.12b & $9.00 \pm 0.87$ & $10.17 \pm 1.04$ & 2250 & 3371 \\
SW2.1dl & $8.00 \pm 0.00$ & $10.17 \pm 1.89$ & 1400 & 3371 \\
BL2.12 & $6.83 \pm 1.04$ & $8.67 \pm 0.58$ & 532 & 1958 \\
BL1.2 & $7.00 \pm 0.50$ & $8.67 \pm 1.15$ & 650 & 1958 \\
BL1.9b & $7.33 \pm 0.58$ & $10.50 \pm 0.87$ & 886 & 3713 \\
BL2.4 & $7.67 \pm 0.29$ & $9.00 \pm 1.00$ & 1141 & 2250 \\
BL2.13 & $8.50 \pm 0.50$ & $9.83 \pm 2.02$ & 1813 & 3031 \\
BL1.4 & $6.83 \pm 1.61$ & $10.00 \pm 0.00$ & 532 & 3200 \\
BL1.11 & $7.33 \pm 1.15$ & $10.17 \pm 0.76$ & 886 & 3371 \\
BL2.10a & $7.50 \pm 0.50$ & $10.67 \pm 0.58$ & 1013 & 3892 \\
CN11a & $8.50 \pm 1.50$ & $9.00 \pm 0.00$ & 1813 & 2250 \\
\hline
\end{tabular}

with proteolytic enzymes proteinase- $K$ and papain. This condition indicated that the antimicrobial compound of CN1.10a has similar characteristic as bacteriocin. The inhibitory mechanism as shown by CN1.10a is namely bacteriocinogenic (Osmanagaoglu et al., 1997). Todorov \& Dicks (2005) reported complete inactivation or significant reduction in bacteriocin activity of cell free supernatant after treated with proteinase $\mathrm{K}$, pronase and trypsin. Proteinase- $\mathrm{K}$ and pepsin were strongly inhibited the activity of bacteriocin, while $\alpha$-amilase, DNase, RNase and lipase were unable to inhibit the activity (Rajaram et al., 2010). On the other hand, SW2.11 isolate showed high antimicrobial activity, its activity however was not lose after being treated with proteolytic enzymes. Therefore SW2.11 isolate was not considered as bacteriocin. The inhibitory mechanism of this strain may be be due to the substrate competition or acidification of the media (Abrams et al., 2011). Based on this result, only bacteriocin produced by $\mathrm{CN} 1.10 \mathrm{a}$ was further characterized.
Several studies reported similar results. The activity of bacteriocin was completely inhibited by proteolytic enzyme (i.e papain, proteinase-K, trypsin, chymotrypsin) indicating that the bacteriocin is proteinaceous in nature, such as Pediocin FA (Osmanagaoglu et al., 1997), bacteriocin from $L$. plantarum $\mathrm{F} 1$ and $L$. brevis OG1 (Ogunbanwo et al., 2003), bacteriocin from L. plantarum ST194BZ (Todorov and Dicks., 2005), bacteriocin from Leuconostoc mesenteroides E131 (Xiraphi et al., 2008), bacteriocin bacPPK34 (Abrams et al., 2011), bacteriocin UN01 and bacteriocin from L. fermentum (Udhayashree et al., 2012).

Bacteriocin produced by CN1.10a isolate was active at $\mathrm{pH}$ 2-6 after incubation for $4 \mathrm{~h}$ (Table 5). The activity might be lost by proteolytic degradation, protein aggregation or instability of proteins (Aasen et al., 2000 in Todorov et al., 2011). Different observations have been previously reported where bacteriocin R1333 and ST16Pa remain stable after incubation $\left(30^{\circ} \mathrm{C}\right)$ at $\mathrm{pH} 2,4,6,8,10$ and 12 , while 
Table 4. Effect of proteolytic enzyme on bacteriocin activity

\begin{tabular}{|c|c|c|c|}
\hline \multirow{2}{*}{ Treatments } & \multirow{2}{*}{ Concentration $(\mathrm{mg} / \mathrm{ml})$} & \multicolumn{2}{|c|}{ Bacteriocin activity $\left.{ }^{*}\right)$} \\
\hline & & CN1.10a & sW2.11 \\
\hline Control (without enzyme) & - & + & + \\
\hline Proteinase-K & 0.1 & - & + \\
\hline Ribonuklease-A & 0.1 & + & + \\
\hline Papain & 0.1 & - & + \\
\hline
\end{tabular}

$\left.{ }^{*}\right)$ L. plantarum was used as tested bacteria

Table 5. Effect of pH on bacteriocin activity

\begin{tabular}{cc}
\hline $\mathrm{pH}$ & Bacteriocin activity $\left.(\mathrm{AU} / \mathrm{ml})^{*}\right)$ \\
\hline 2 & 2.056 \\
4 & 2.023 \\
6 & 2.307 \\
8 & 0 \\
10 & 0 \\
\hline$\left.{ }^{*}\right)$ L. plantarum was used as tested bacteria
\end{tabular}

bacteriocin from $L$. brevis OG1 is stable at $\mathrm{pH} 2$ to 8 (Ogunbanwo et al., 2003; Todorov et al., 2011).

As shown in Table 6, bacteriocin produced by $\mathrm{CN} 1.10 \mathrm{a}$ had strong heat stability even after being autoclaved at $121^{\circ} \mathrm{C}$ for $15 \mathrm{~min}$. Based on this characteristic, bacteriocin from CN1.10a has a potential to be used as a preservative for high temperature processed food. It might offer another application in the processing and preservation of various foods (Gao et al., 2010) such as fermented fish sausage, salami, etc. Similar results were reported, $L$. brevis OG1 bacteriocin was very heat stable, the activity was not reduced after heating at $121^{\circ} \mathrm{C}$ for $60 \mathrm{~min}$, while bacteriocin from $L$. plantarum $\mathrm{F} 1$ exhibit full activity after heating at $121^{\circ} \mathrm{C}$ for 10 $\mathrm{min}$. Other research reported that bacteriocin ST16Pa remains stable after $2 \mathrm{~h}$ heating at $25,30,37,45,60$, 80 or $100^{\circ} \mathrm{C}$ and no decrease in activity after heat treatment at $121^{\circ} \mathrm{C}$ for $20 \mathrm{~min}$ at $\mathrm{pH} 6.0$ (Ogunbanwo et al., 2003; Todorov \& Dicks, 2006; Todorov et al., 2011).

Figure 1 showed the effect of surfactant on bacteriocin activity. Among the surfactants, EDTA, SDS and laurylsarcosine stimulated CN1.10a bacteriocin activity, but not Triton X-100, Tween 20, Tween 80 and Urea. In the contrary, Todorov \& Dicks (2006); Todorov et al. (2011) \& Castro et al., (2011) reported that treatment with Tween 20 , Tween 80 , urea, Triton X-100 and Triton X-114 have no effect on the activity of bacteriocin R1333, L. sakei ACU and plantaricin C19. However, Tween 20 enhances bacteriocin activity.

In the present study, EDTA had effect on CN1.10a bacteriocin activity against $S$. aureus. EDTA is used in food product to prevent oxidation, it also has antimicrobial activity especially against Gram negative bacteria. EDTA has ability to disturb the highly structure of the outer membrane and allow access of hydrophobic molecules to the cytoplasmic membrane (Vaara, 1992 in Castro et al., 2011). Therefore, it can be assumed in this case, it might sensitizes $S$. aureus membrane. Because bacteriocin do not act equally against target species, many researchers have examined the affinity of bacteriocin to specific species and strains (Castro et al., 2011).

Meanwhile non-ionic surfactant Triton X-100, Tween 80 and Tween 20 had no effect on bacteriocin activity, although other research was reported that addition of non-ionic surfactants to various food constituents could induce production of bacteriocins. Tweentreated cultures also increased the supernatant activity relative to total activity, probably by deadsorption and disaggregation. However the effects were strain dependent (Reese \& Maguire,1969 in Castro et al., 2011). In addition, the exposure of $\mathrm{CN} 10$ a bacteriocin to surfactants resulted an increasing of 


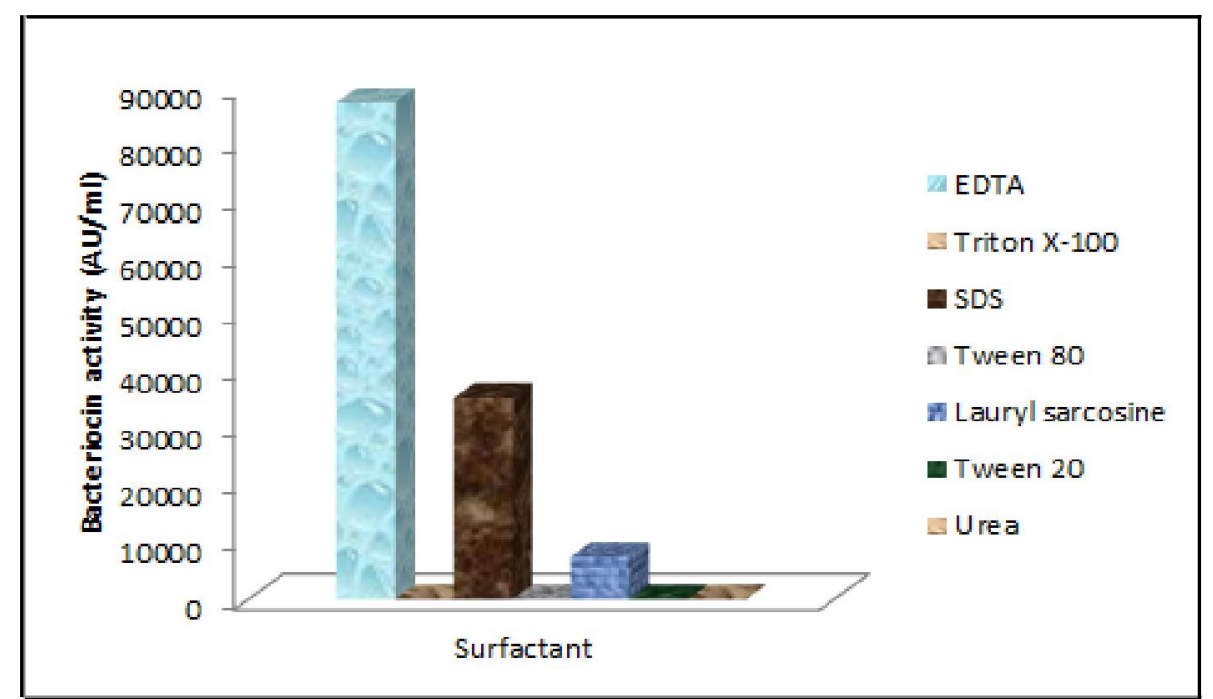

Figure 1. Effect of surfactant on the activity of CN1.10a bacteriocin to $S$. aureus.

Table 6. Effect of temperature on bacteriocin activity

\begin{tabular}{rc}
\hline Treatment & Bacteriocin activity (AU/ml) \\
\hline $80^{\circ} \mathrm{C}$ for $20 \mathrm{~min}$ & 10.244 \\
$115^{\circ} \mathrm{C}$ for $20 \mathrm{~min}$ & 8.605 \\
$121^{\circ} \mathrm{C}$ for $15 \mathrm{~min}$ & 3.197 \\
\hline
\end{tabular}

${ }^{*}$ ) L. plantarum was used as tested bacteria

Table 7. Spectrum of antibacterial activity

\begin{tabular}{lcc}
\hline \multicolumn{1}{c}{ Indicator strain } & Inhibition zone $(\mathrm{mm})$ & Bacteriocin activity (AU/ml) \\
\hline L. plantarum & 11.7 & 5.045 \\
L. monocytogenes & 9.0 & 2.25 \\
S. thypimurium & 0 & 0 \\
E. coli & 10.3 & 3.505 \\
\hline
\end{tabular}

bacteriocin titre. This increase might be due to the effect of surfactant on the permeability of the cell membrane (Ogunbanwo et al., 2003).

Antibacterial activity of $\mathrm{CN} 1.10$ a bacteriocin exhibited a small target activity (Table 7 ). It was able to inhibit L. plantarum, L. monocytogenes, E. coli and but not $S$. thypimurium. LAB bacteriocin tend to be active against a wide range of mostly Gram positive bacteria, while Gram negative bacteria are generally insensitive to bacteriocin from $L A B$ because they have a thinner layer ( $10 \%$ of cell wall), and an outer membrane (OM) which providing a permeability barrier.
Outer membrane on contains lipids and is separated from the cell wall by the periplasmic space. The permeability barrier property of the OM is largely due to the presence of a specific lipopolysaccharide (LPS) layer on the membrane surface. LPS molecules consist of a lipid part, termed lipid A, and a hydrophilic heteropolysaccharide chain protruding outward and providing the cell with a hydrophilic surface (Hwanhlem et al., 2011). Meanwhile Gram-positive bacteria only have a thick mesh-like cell wall, made of peptidoglycan which constructs about $90 \%$ of the cell wall (Helander et al., 1996 in Omar et al., 2006). 
Table 8. Physiological and biochemical characteristics of bacteriocin producing strain

\begin{tabular}{ll}
\hline $\begin{array}{l}\text { Physiological and biochemical } \\
\text { characteristic }\end{array}$ & \multicolumn{1}{c}{ Result } \\
\hline Colony morphology & Creamy, smooth round colonies \\
Gram staining & Gram positive, coccus \\
Growth in MRS broth & turbid \\
Fermentation reaction & $\begin{array}{l}\text { ribose, galactose, D-glucose, D-fructose, D-mannose } \\
\text { amygdalin, arbutin, esculin ferric citrate, salicin, }\end{array}$ \\
& D-cellobiose, D-maltose, D-lactose, D-saccharose, \\
& D-trehalose, D-gentobiose, \\
Catalase & Negative \\
Oxidase test & Negative \\
Identification & Lactococcus lactis subsp. lactis \\
\hline
\end{tabular}

\section{Identification of Isolate CN1.10a}

Based on the physiological and biochemical characteristic tested using API $50 \mathrm{CHL}, \mathrm{CN} 1.10 \mathrm{a}$ isolate was identified as Lactococcus lactis ssp. lactis. The $\mathrm{CN1} 10 \mathrm{10}$ isolate was Gram positive, coccus, catalase negative and oxidase negative. The strain was capable in fermenting sugar such as ribose, galactose, glucose, fructose, mannose, cellobiose, maltose, lactose, saccharose, trehalose and gentobiose (Table 8).

\section{CONCLUSION}

CN1.10a which was identified as Lactococcus lactis sp. lactis which was isolated from rusip, a fermented fish from Bangka, produced bacteriocin that sensitive to proteolytic enzymes, i.e. proteinase $\mathrm{K}$ and papain but not to RNAse. The bacteriocin has wide inhibition activity against Gram positive and negative bacteria such as Esherichia coli, Listeria monocytogenes and Lactobacillus plantarum. The bacteriocin was stable at $\mathrm{pH} 2.0$ to 6.0 and its activity could be stimulated by sodium dodecyl sulphate (SDS), lauryl sarcosine and EDTA surfactans but strongly inhibited by Tween 20, Tween 80 , Triton X100 and urea. This bacteriocin was heat stable $\left(121^{\circ} \mathrm{C}\right)$, therefore it has potential to be used as a preservative for high temperature processed foods.

\section{ACKNOWLEDGMENTS}

We thank to Prof. Dr. Endang Sri Heruwati and Prof. Dr. Endang S. Rahayu for helpful discussions. We also thank to Yusma Yennie, the head of Microbiology Laboratory, Research and Development
Center for Marine and Fisheries Product Processing and Biotechnology for her technical assistance and provision of laboratory facilities.

\section{REFERENCES}

Abrams, D., Barbosa, J., Albano, H., Silva, J., Gibbs, P and Teixeira, P. 2011. Characterization of bacPPK34 a bacteriocin produced by Pediococcus pentosaceus strain K34 isolated from "Alheira". Food Control. 22: 940-946.

Alegria, A., Delgado, S., Roces, C., Lopez, B and Mayo, B. 2010. Bacteriocins produced by wild Lactococcus lactis strains isolated from traditional, starter-free cheeses made of raw milk. International Journal of Food Microbiology. 143: 61-66.

Biscola, V., Todorov, S.D., Capuano, V.S.C., Abriouel, H., Galvez, A., and Franco, B.D.G.M. 2013. Isolation and characterization of a nisin-like bacteriocin produced by a Lactococcus lactis strain isolated from charqui, a Brazilian fermented, salted and dried meat product. Meat Science. 93: 607-613.

Budde, B.B., Hornbaek, T., Jacobsen, T., Barkholt, V, and Koch, A.G. 2003. Leuconostoc carnosum 4010 has the potential for use as a protective culture for vacuumpacked meats: culture isolation, bacteriocin identification, and meat application experiments. International Journal of Food Microbiology. 83 : 171184.

Castro, M.P., Palavecino, N.Z., Herman, C., Garro, O.A., Campos, C.A. 2011. Lactic acid bacteria isolated from artisanal dry sausages: Characterization of antibacterial compounds and study of the factors affecting bacteriocin production. Meat Science. 87 : 321-329.

Cleveland, J., Montville, T. J., Nes, I. F., and Chikindas, M. L. 2001. Bacteriocins: Safe, natural antimicrobials for food preservation. International Journal of Food Microbiology. 71: 1-20. 
De Arauz, L. J.,Jozala, A.F., Mazzolab, P. V., Vessoni and T.C., Pennaa. 2009. Nisin biotechnological production and application: a review. Trends in Food Science and Technology. 20 :146-154.

De Vuyst, L., \& Vandamme, E. J. (1994). Bacteriocins of Lactic Acid Bacteria: Microbiology, genetics and applications. London: Blackie Academic and Professional.

Galvez, A., Abriouel, H., Lopez, R. L and Omar, N.B. 2007. Bacteriocin-based strategies for food preservation. International Journal of Food Microbiology. 120: 5170.

Gao, Y., Jia, S., Gao, Q and Zhilei. 2010. A novel bacteriocin with broad inhibitory spectrum produced by Lactobacillus sake $\mathrm{C} 2$, isolated from traditional Chinese fermented cabbage. Food Control. 21 (2010) 76-81.

Hilmi CË on, A and GoĖ kalp, H. Y. 2000. Production of bacteriocin-like metabolites by lactic acid cultures isolated from sucuk samples. Meat Science. $55: 89$ $-96$.

Hwanhlem, N., Buradaleng, S., Wattanachant, S., Benjakul., Tani, A and Maneerat S. S. 2011. Isolation and screening of lactic acid bacteria from Thai traditional fermented fish (Plasom) and production of Plasom from selected strains. Food Control. 22 (2011) 401-407.

Karthikeyan, V and Santhosh, S.W. 2009. Study of bacteriocin as a food preservative and the $L$. acidophilus strain as probiotic. Pakistan Journal of Nutrition 8 (4): 335-340.

Klaenhammer, T. R. (1988). Bacteriocins of lactic acid bacteria. Biochimie. 70: 337"349.

Kusmarwati, A., Darmosuwito, S., dan Lelana, I,Y. B. 2001. Observation of Staphylococcus aureus bacteria on traditional fish product in Bangka Regency.. J. Fish Sci. 3 (1): 1-8.

Kusmiati and Malik, A. 2002. Bacteriocin activity of Leuconostoc mesenteroides Pbac1 bacteria on several media. Makara, Health. 6 (1): 1-7.

Liu, G., Lv, Y., Li, P., Zhou, K and Zhang, J. 2008. Pentocin $31-1$, an anti-Listeria bacteriocin produced by Lactobacillus pentosus 31-1 isolated from Xuan-Wei Ham, a traditional China fermented meat product. Food Control 19 : 353-359.

Nugroho, D. A and Rahayu, E. S. 2003. Extraction and characterization of bacteriocin produced by Leuconostoc mesenteroides SM 22. J. Technol and Food Industry. 14 (3) : -

Ogunbanwo, S.T., Sanni, A.I and Onilude, A.A. 2003 Characterization of bacteriocin produced by Lactobacillus plantarum $\mathrm{F} 1$ and Lactobacillus brevis OG1. African Journal of Biotechnology Vol 2 (8): 219227.

Omar, N. B., Abriouel, H., Lucas, R., Martinez-Canamero, M., Guyot, J and Galvez, A. 2006. Isolation of bacteriocinogenic Lactobacillus plantarum strains from ben saalga, a traditional fermented gruel from Burkina Faso. International Journal of Food Microbiology 112 : 44-50.

Osmanagaoglu, O., Gunduz, U., Beyatli, Y and Cokmus, C. 1997. Purification and characterization of Pediocin F.A bacteriocin produced by Pediococcus acidilactici F. Tr. J. of Biology. 22: 217-228.

Rahayu, E.S. and Margino, S. 1997. Lactic acid bacteria: Isolation and identification. Food and Nutrition UGM, Yogyakarta. 13-14

Rahayu, E.S., Ekasari, A., Wardhani, A.K, and Margino, S. 1999. Screening of lactic acid bacteria from meat and meat product as bacteriocin producer. Proceeding of Food National Conference, Yogyakarta September 14, 1999.

Rajaram, G., Manivasagan, P., Thilagavathi, B and Saravanakumar, A. 2010. Purification and characterization of a bacteriocin produced by Lactobacillus lactis isolated from marine environment. Advance Journal of Food Science and Technology 2(2) : 138-144.

Sakti, T, P, J. 2009. Analysis probiotic of lactic acid bacteria from rusip. Bachelor Thesis. Departement of Agriculture Sriwijaya University. 35 pp.

Syahniar, T. M. 2009. Production and Characterization of bacteriosin from Lactobacillus plantarum $1 \mathrm{~A} 5$ and antimicrobial activity to pathogen bacteria. Thesis. IPB Bogor. $61 \mathrm{pp}$

Todorov, S.D and Dicks. 2005. Effect of growth medium on bacteriocin production by Lactobacillus plantarum ST194BZ, a strain isolated from Boza. Food Technol Biotechnol. 43: 165-173.

Todorov, S. D and Dicks, L.M.T. 2006. Screening for bacteriocin-producing lactic acid bacteria from boza, a traditional cereal beverage from Bulgaria Comparison of the bacteriocins. Process Biochemistry $41: 11-19$.

Todorov, SD., Rachman, C., Fourrier, A., Dicks, Leon MT., Van Reenen., Pre'vost, H and Dousset, X. 2011. Characterization of a bacteriocin produced by Lactobacillus sakei R1333 isolated from smoked salmon. Anaerobe 17 : 23-31.

Udhayashree, N., Senbagam, D and Senthilkumar, B. 2012. Production of bacteriocin and their application in food products. Asian Pacific Journal of Tropical Biomedicine: S406-S410.

Usmiati, S and Marwati, T. 2007. Selection and optimation of process of bacteriocin production from Lactobacillus sp. J. Post Harvest. 4 (1) : 27-37.

Xiraphi, N., Georgalaki, M., Rantsiou, K., Cocolin, L., Tsakalidou, E and Drosinos, E.H. 2008. Purification and characterization of a bacteriocin produced by Leuconostoc mesenteroides E131. Meat Science 80: 194-203.

Yuliana, N. 2007. Profile of rusip fermentation made from anchovies (Stolephorus sp). Agritech. 27 (1) : 12-17. 